\title{
Imperial Treaties and the Origins of British Colonial Rule in Southern Nigeria, 1860-1890
}

\author{
Anietie A. Inyang, (Ph.D) \\ Department of History and International Studies, University of Uyo, Nigeria \\ Email: anietieainyang@yahoo.com \\ Manasseh Edidem Bassey, (Ph.D) \\ Department of Political Science and Public Administration, University of Uyo, Nigeria \\ Email:mannbass@rocketmail.com
}

\section{Doi:10.5901/mjss.2014.v5n20p1946}

\section{Abstract}

How did treaties, entered into with the aid of Britain, the effective penetration of the Nigeria's geo-political space? British control and spread into the hinterland from Lagos and from the lower reaches of the Niger was achieved through the effective employment of the instrument of treaties. The eventual British colonial acquisitions in Nigeria were preceded by a treaty-making phase during which the powers signed agreements with the local authorities to formalise their interests. These were the same documents (i.e treaties) that were conceived to establish political claims thereafter and defined Nigeria's geo-political boundaries. The paper argues that colonialism presented the effective manipulation of British designed treaties for the furtherance of British trade and commerce.

Keywords: Treaties, Sovereignty, Protectorates, Colonial government, empire

\section{Introduction}

Britain gained control of Nigeria through both diplomatic (treaties) and military (gun-boat) means. By 1914, Britain had gained effective control of the entire area of Nigeria as a colony. Treaties defined the character of the British penetration in such a way that when in 1900 political control was formally established over the Nigerian area, it took the tripartite form of three autonomous administrations - The Colony and protectorate of Lagos; the Protectorate of Southern Nigeria; and the Protectorate of Northern Nigeria. These three region-like protectorates became subsequently amalgamated in 1914 to form the Nigerian state.

Britain assumed this 'right' to impose its will on Nigeria with the appointment of John Beecroft as the first Consul for the Bights of Biafra and Benin in 1849 which marked the beginning of direct British influence in Nigeria. The British generally dictated treaties that resulted in further annexations and eventual colonialism. Colonial administration in Nigeria was a direct consequence of the various attempts to stamp out slave trade and establish 'legitimate commerce' which was patterned after the industrial and commercial needs of Britain and latter Europe. An effective suppression of the slave trade (which needed to start from the hinterland) could only be achieved without the use of treaties. The slave-trade treaties thus provided the legal and diplomatic strength to put a stop to a trade that was no longer profitable to the commercial and industrial demand of Britain - the trailblazer of the industrial revolution. The need to ensure that clauses of the various treaties were upheld led to the increased involvement of Britain with the political and social life of the hinterland states (Starting with the coastal state of Lagos) which evolved into the Nigerian state.

\section{Treaties and the Colonial Penetration of Nigeria}

Colonialism is a system of rule which assumes the right of one people to impose their will upon another leading inevitably to a situation of dominance and dependency which will systematically subordinate those governed by it to the imported culture in social, economic and political life (Brett, 1973, p.30). The conquest of non-European peoples for economic and political advantage was the most important feature of the $19^{\text {th }}$ century, which was termed by historian Eric Hobsbawn (1987), as the 'Age of Empire'. In Nigeria, colonialism as a new social force in an indigenous society led to significant changes in her social, economic and political structures.

As it transpired, British determination to put an end to the slave trade in the end prepared the way for the eventual 
British occupation. As we have seen in the appointment of a Consul for the Bights of Biafra and Benin, this was due to representations made to the British Government by British traders that a person should be appointed to reside in that part of Africa as agent on the part of Britain. This was mainly for purpose of regulating trade between British merchants and Old Calabar, Bonny, Bimbia, the Cameroon and the parts of the territories of the King of Dahomey (Orugbani, 2005, p.84). It was in response to such request that the British Government decided to make such an appointment with Beecroft as the first Consul.

It is significant that within a few months of his appointment as Consul in 1849, Beecroft became directly involved in the affairs of Lagos. This was the first case of the enforcement of treaties leading directly to the imposition of British authority. Beecroft deposed Kosoko, the slave-trading king of Lagos and installed Akintoye. Why was Lagos so strategic and important to Britain? Lord Palmerston, the then British Foreign Secretary had argued categorically that:

\begin{abstract}
If Lagos, instead of being a nest for slave-traders were to become a port of lawful trade, it would become an important outlet for the commerce of a large range of country in the interior, and instead of being a den of barbarism, would become a diffusing centre of civilisation (Uzoigwe, 1985, p.43).
\end{abstract}

In England, the missionaries also lobbied the government to abolish the slave trade in Lagos and when Bishop Samuel Crowther was received by Her Majesty Queen, he was of the view that 'the slave trade on that part of the African coast would be at an end if Lagos the stronghold of its greatest supporter was destroyed'.(Burns \& Collins, 2007, p.112) As previously argued one of the basic instrument manipulated by Britain to suppress the slave trade were treaties which were entered into with the various chiefs. However, scholars like Crowder (p.27) argue that European interest in establishing commercial relations with the interior of West Africa had preceded the abolition of the slave trade and was not imbued with humanitarian motives ${ }^{6}$ If this is true, then it stands that the slave trade treaties did not solely provide the basis for the establishment of colonial rule in Nigeria.

Be it as it may, the suppression of the overseas slave trade brought about a new trend in Euro-Nigerian relations. From the late fifteenth century, when Europeans began trading with the coastal peoples of Nigeria, until the beginning of the nineteenth century, a noticeable feature of the relations between them and the indigenous people was their complete dependence on the rulers of the coastal peoples not only for the securing of trade but also for the safety of their lives and property. Ikime (1977:3) argues that In Nigeria, unlike the situation in Ghana, the European nations which engaged in trade with the people of Nigeria did not build any forts along the coast except for the naval squadron that undertook a blockade of the major slave trading ports of Nigeria. The British found they could compete with other European powers in the Coast of Nigeria only by forming national trading companies. The first of such effective English enterprise was the Company of the Royal Adventurers, chartered in 1660 and succeeded in 1672 by the Royal African Company(Ibid., p.3).

In the absence of fortified military bases, treaties played a huge role in ensuring that the source of supply of slaves were blocked and this eventually led to their direct involvement with the politics and administration of Nigeria against reluctant pro-slave trade chiefs. Thus, if Britain found herself using force to suppress the overseas slave trade, which is not to say that she regarded force as the best means of achieving the desired end. Britain sought other means, less of force, to achieve her end. One of such means was the use of treaties. Treaties with coastal states contained clauses which provided that in return for giving up the trade in slaves, the rulers of these states would be paid certain compensation over an agreed number of years. Usually the agreed compensation was trifling when compared with the revenue hitherto derivable from the slave trade (Hopkins, 1975, p.159). However, while these treaties made provisions for protecting lives and property of British traders, it made no similar provision for the protection of these coastal states.

At this point, one should stress the relationship between treaties and the use of brute force. Treaties further legitimised the strength of the British gunboats. The importance of these treaties was that once signed, the British used them as the excuse for bombarding Nigerian states on the grounds that one or other treaties of the article had been broken. However, it was rather quite difficult if not impossible for local traders to keep to all clauses of any treaty. Extracted examples of such clauses read:

The Chiefs of... agree and promise to refrain from entering into any correspondence, Agreement, or Treaty with any Foreign Nation or Power except with the knowledge and sanction of Her Britannic Majesty's Government (Hertslet, 1967, p.120).

\title{
Another one read:
}

The Chiefs of... hereby engage to assist the British Consular or other officers in the execution of such duties as may be assigned to them; and further, to act upon their advice in matters relating to the administration of justice, the 
development of the resources of the country, the interest of commerce, or in any other matter in relation to peace, order, and good government, and the general progress of civilisation (Ibid.).

The various treaties by and large made them very vulnerable and susceptible to British revenge through military force. One might thus be tempted to assume that the essence of the treaties were just to prepare legitimate as well as convinced moral reasons for the use of brute force and the unavoidable temptation to usurp political and economic authority from the local subjects.

During the period when Nigeria was colonised, most of the Nigerian rulers and their people were illiterate in English. It therefore followed that the same agents who negotiated the treaties took the trouble to learn the local language so as to be able to communicate with the indigenous people. It would naturally follow from this practice that the interpreters' declaration, in whichever language it was made, raise a doubt as to whether it was bona fide. In any case, even if it was bona fide for the African chief and their councillors were not given enough time to discuss the proposals in detail in order to unveil the present and future social, economic, and political consequences or implication of the treaty. And further, if in some instances they did discuss the terms of the treaty in detail, it was highly improbable that they would identify the policy behind the standard form treaties as determined under the Berlin Conference.

After Lagos fell into the grip of British colonialism in 1861, the British made their way inland, slowly bringing Yorubaland under British rule. The first major coup in the hinterland occurred in 1886, when the British intervened to end the ardous Ekitiparapo War between Ibadan and the alliance of Ekiti, ljesa, Egba, ljebu, and Ife forces. All sides were weary of fighting this war, which had been going on for fifteen years, and welcomed the British as peacemakers (Folola \& Heaton, 2008, p.95). The British terms designed in a standard treaty, while bringing an end to the main fighting of the war, opened the door to full-scale colonisation, however. The treaty ending the war declared that all signatory combatants would direct future disputes with each other to the British governor in Lagos for resolution. Furthermore, all parties agreed to the promotion of free trade, which translated into greater access for British commercial interests into interior markets.

The British used this treaty as justification for the occupation of ljebuland in 1892. The ljebu had always been suspicious of the motives of Europeans in their country - whether missionary, commercial, or political agents - and had outlawed them entirely for most of the nineteenth century. When the ljebu king refused to discuss trade terms with the acting governor of Lagos on a trip to ljebuland in 1891, the British used this as an excuse to occupy the territory forcibly. British troops subdued ljebu in four days of fighting, sending a message to the rest of Yorubaland that the British were the new supreme power in the region and were willing to use their superior military machinery to get their way (Ryder, 1969, p.267). When the British officials circulated a new treaty of protection to the Yoruba states in 1893, most Yoruba leaders saw the writing on the wall and signed away their sovereignty, becoming part of the expanded Colony and Protectorate of Lagos.

British colonial penetration built upon the spheres of influence secured under the thick cloud of imperialism. Suffice it to note that spheres of influence and protectorate were among the most important institutions of colonialism. However, both spheres of influence and protectorates were the product of treaties though more political than legal. As such the very idea of a sphere of influence implied potentially the protectorate. Derivative upon this, a sphere of influence was, where possible, usually prelude to a protectorate, and a protectorate to a colony.

\section{The British Courts of Equity and the Defence of Commercial Treaties}

Consuls were appointed by the British for the purpose of regulating trade between the British and the indigenous merchants. The British appointed the first consul in 1849 and in 1850 the Court of Equity was established in Bonny (Ikime, 1977, p.31). The court was made up of a majority of European supercargoes and leading Bonny traders. It should be pointed out that the jurisdiction of the court extended then to Dahomey, now Benin Republic, to the Cameroons. It thus covered the whole of the coastal area of modern Nigeria. The main function of the court was originally to settle disputes arising from trade between European supercargoes and delta traders with John Becrooft as the chairman of the court.

There is no doubt that the establishment of such a tribunal nevertheless challenged the sovereignty of the Delta area. Making the British consul chairman and endowing the court with a majority of European supercargoes marked an important inroad into the sovereignty of Bonny. In 1856, a court of equity was also established in Calabar to settle disputes between British firms and local traders. The court was made up of a group of voting members, a majority of whom came from the major British firms, with the consul himself as chairman. Because of the make-up of the court, decisions rarely favoured local dealers. The composition of that court was even more unfavourably weighted for although a number of Efik rulers and chiefs sat on it, only the rulers of Creek Town and Duke Town had a vote half the membership of the was made up of European supercargoes, each of whom had a vote. The Calabar court was thus, in 
terms of voting, a British controlled court (Folola \& Heaton, 2008, p.98). The granting of judicial authority to such an alien institution simultaneously empowered British trading interest at the expense of local middlemen and undermined the sovereign authority of indigenous rulers in the Bight of Biafra.

In Calabar the conflict which developed between the Efik and the long-established British traders cantered on the manipulation of the trust system by the latter. While the Efik did all they could to take full advantage of the influx of new traders, the British supercargoes sought to push out the new comers. Ultimately, in 1856, the British supercargoes forced an agreement on the Efik leading to the establishment of the Court of Equity in 1856 (Cain \& Hopkins, 1980, p.30). The terms of the treaty provided that if any Efik owed any European trader oil, all other Europeans should refuse to trade until the debt was made good.

Further, once comey had been paid, the trade of European supercargoes was not to be stopped for any reason whatsoever. If this were to happen, the Efik kings would be held responsible and would be liable to a fine of one puncheon of oil per day per hundred tons registered to the ship. If the Efik kings refused for any reason to accept the comey paid by any supercargo, the latter could, nevertheless, begin trading. If an Efik trader was summoned to appear before the Court of Equity but failed to do so, the Efik kings were to be held responsible for producing him within eight days. Thereafter, the Efik kings would be fined 20 pieces of cloth every week until the absentee was brought before the court (Asiegbu, 1984, p.71). Furthermore, appeals against the decision of the Court of Equity were to lie before the British consul. The treaty which brought the court into effect, very similar to the 1851 treaty with the Itsekiri, was one-sided in the extreme and was designed to safeguard the trade of the British supercargoes while undermining the sovereign powers of the Efik rulers.

In an effort to find a solution to the perennial problem of dispute over trade, the British, backed by superior force, were thus able to make important inroads into the sovereignty of the delta states. These inroads were mostly made up of rivers such as Benin River, Escravos River, Forcados River, Dodo River, Fishtown River, Nun River, Brass River etc. These rivers were grand highways of commerce and imperialism. An important point in fact is that the Court of Equity gave manipulating interpretations to treaties made between and among local subjects as well as those made between local subjects and British or other European traders. Bonny is a case in study. As soon as Becrooft was appointed consul, he received letters of complaint from British traders in the Itsekiri kingdom as well as Bonny. The Bonny traders complained that King Pepple of Bonny had stopped all trade as a consequence of non-payment of the compensation promised him. King Pepple requested that the treaty of 1848 be abrogated and that the situation should revert to what it was before the treaty of 1836 was signed. Pepple was thereafter removed and exiled and his removal pointed to the fact that the British consul and traders were determined that if they were to control successfully the trade of Bonny and other delta states, they must also wield predominant political power.

Following on Pepple's exile, a new treaty was signed with the British installed King, Dappo which made the Court of Equity supreme in the government of Bonny. The treaty also forbade the King of Bonny from participating in trade. He was to depend for his revenue solely on custom duties and such like public sources. Only the Court of Equity was to handle trade matters in the future. The King of Bonny was not to go to war unless the British supercargoes in Bonny approved (Ibid., p.86)). All meetings on matters of interest to the two sides were in future to be heard not in the king's house but in the building which housed the Court of Equity. Although evidence is lacking to suggest that these courts were involved in the direct process of treaty making, judgement of cases in these courts were based on treaties. This went further to beef up the relevance of treaties making it a potent instrument in British relations with her local subjects. In a meeting of the Bonny Court of Equity in 1853, Beecroft deposed King Pepple of Bonny, who had recently instigated a war with the town of Elem Kalabari (Folola \& Heaton, 2008, p.97). King Pepple had been a thorn in the side of British trade interests for over twenty years, consistently refusing to give up his control of interior markets and openly engaging in hostilities with anyone who challenge his pre-eminence in these areas. Pepple's successor, Dappo, was forced to sign a treaty that made the court of equity the supreme judicial authority in Bonny. This treaty prevented the king from engaging in trade himself, and prevented the king from waging war without the approval of the British supercargoes.

Bonny declined quickly thereafter, and, with the civil war that led to Jaja's creation of Opobo in 1869, ceased to be the most prominent state in the delta. Jaja's ability to control the hinterland markets from Opobo meant that the European traders, while initially angered by this move, ultimately accepted Jaja as the predominant ruler of the region and officially recognised Opobo in 1873 (Ibid., p.98). By the time of the Berlin Conference in 1884-5, British concerns had ceased to be primarily over how to bypass the coastal middlemen in the Bight of Biafra and had turned towards how to prevent the French and Germans form undercutting British interest, especially on the Niger and Benue. French trading vessels had appeared in the delta in 1880, and the French had developed trading posts at several points on the upper Niger. Meanwhile, Germany was encroaching upon Calabar and Benue from the east, annexing the Cameroons in 1884. Thus, in 1884-5, the British consul, Hewett, traversed the entire coastal region from Calabar into the western delta, and, through 
the power of his office, had little difficulty convincing local rulers to sign his treaties of protection.

These treaties essentially gave Britain political sovereignty over the signer's territory, allowing the British to conduct foreign relations on the part of the ruler and to interfere in local politics in the interest of peace and free trade. Even Jaja signed a treaty, although warily and with reservations. In 1885 Hewett declared the setting up of the Oil Rivers Protectorate in the name of the United Kingdom. When Jaja latter violated the terms of the treaty of protection by continuing to deny British traders access to his hinterland markets, he was deposed and deported in 1894 after refusing British traders access to the Urhobo markets of his hinterland. After Jaja's deportation, Britain made a far flung prong into the hinterland consolidating the gains of colonialism.

\section{The Royal Niger Company Treaties and the Delta Hinterland}

A major feature of the 1860s and 1870s was the gradual push of European traders into the Niger Valley and the delta hinterland. Macgregor Laird's firm had established trading stations at Aboh, Onitsha, and Lokoja as from the 1850s. By 1860s the West Africa Company, Messrs Millers Brothers and Co., the Central African Trading Company, James Pinnock and Co. - all these had pushed their way into Akasa, Aboh, Ndoni, Onitsha, and other areas of the Niger Valley. For most of the first half of the nineteenth century only large or otherwise well-organised European firms could cope with the cost and problems of the delta trade which was marked by considerable tension and turbulence. Such tensions led to the signing of the Aboh Treaty to prevent future attacks on British commerce after the Obi of Onitsha had organised the looting of Macgregor Laird's stores and was thereafter punished with a naval bombardment (Tamuno, 1965, p.274). In 1879 conflicts between Onitsha and the United Africa Company resulted in the bombardment of that town. In 1882, Akassa, Patani, Asaba, and Idah suffered a similar fate. Increased tension between Nigerian groups and European Firms was matched by increased competition between the many European firms which operated in the delta and Niger Valley in the 1860 s and 1870 s.

It is very likely that such increased competition and tension not only led to declining profits but also weakened the bargaining position and treaty-negotiation strength of the European firms vis-à-vis the various Nigerian groups. It was in an effort to overcome this situation that Taubman Goldie, who arrived in the Niger Delta in the late 1870s, gradually amalgamated various British firms into what by 1879 had become one huge concern, the United Africa Company (which soon became known as the National African Comapany). Two years later Goldie succeeded in buying off all the French companies operating in the delta and Niger Valley making the area a British sphere of influence. In 1886, Goldie obtained a Royal Charter for the National Africa Company which then became the Royal Niger Company. According to Ikime (1977:119):

The obtaining of a charter meant that the company was not just a trading concern; it had conferred on it certain powers of government and law making, as well as powers to raise and maintain an armed force for the effective pursuit of its trade as well as for the maintenance of law and order.

Such a grant was a deliberate act by which Britain sought to guarantee her interests on the Niger-Benue as well as parts of the delta. The need to guarantee this interest had become urgent as a consequence of the activities of other European powers, notably France and Germany, in what has become known in history as 'the scramble for Africa'.

Four years before the National African Company obtained its charter, Consul Hewett had travelled across the length and breadth of the Niger Delta and signed treaties of 'protection' with various rulers and peoples from the Cameroons in the East to the River Forcados in the West. In January 1890, a treaty of protection was entered into by the Emir and Chiefs of Boussa (Borgu) with the Royal Niger Company. It read:

We the Emir and Chiefs of Boussa (or Borgu), in Council assembled (representing our country, its dependencies, and tributaries on both banks of the River Niger, and as far back as our dominion extends, in accordance with our law and customs), do hereby agree, on behalf of ourselves and our successors for ever to grant the Company full and absolute jurisdiction over all foreigners to our territories - that is to say, over all persons within the territories who are not our native-born subjects. Such jurisdiction shall include right of protection of such foreigners, of taxation of such foreigners, and of political, criminal, and civil jurisdiction over such foreigners.

We will not at any time whatever cede any of our territories to any other person or State, or enter into any Agreement, Treaty, or arrangement with any foreign Government, except through and with the consent of the Company... and to place our territories, if and when called upon to do so by the Company, under the protection of the flag of Great Britain (Hertslet, p.120). 
By 1884 the delta states had become extremely preoccupied with securing their middleman position in the face of the push by European into the Niger Valley. Connected with concern over trade was concern over the labour supply necessary to make that trade profitable. These treaties were patterned after a particular attainment and Hertslet provides an example of such treaty signed and entered into in 1885. It read:

\begin{abstract}
We, the undersigned King and Chiefs... with the view to the bettering of the condition of our country and people, do this day cede to the National Africa Company (Limited), their heirs and assigns, forever, the whole of our territory...We also give the said National African Company (Limited) full power to settle all native disputes arising from any cause whatever, and we pledge ourselves not to enter into any war with other tribes without the sanction of the said National Africa Company (Limited).

We also understand that the said National African Company (limited) have full power to mine, farm, and build in any portion of our territory. We bind ourselves not to have any intercourse with any strangers or foreigners except through the said national African Company (Limited), and we give the said National African Company (Limited) full power to exclude all other strangers and foreigners from their territory at their discretion.

In consideration of the foregoing, the said National African Company (Limited) bind themselves not to interfere with any of the native laws or customs of the country, consistently with the maintenance of order and good government...[and] agree to pay native owners of land a reasonable amount for any portion they may require.

The said National African Company (Limited) bind themselves to protect the said King and Chiefs from the attacks of any neighbouring tribes (Ibid.).
\end{abstract}

This was the same pattern even after the Company became chattered and limited and when it metamorphosed into the National African Company (Limited). Suffice to mention that an interpreter was always made available to explain the various clauses of the treaties which the King and chiefs did not understand. In such cases, a declaration was also singed the interpreter who in most cases was a native of that locality but could at least fluently read and speak both languages. Such a declaration was patterned after the sample captured by Hertslett below:

$I, \ldots$ native of ...., do hereby solemnly declare that I am well acquainted with the ... language, and that on the ... day of ...., 1885, I truly and faithfully explained the above Agreement to all the Chiefs present, and that they understood its meaning (Ibid., p.133).

In most cases, these interpreters dared not tell the rulers, irrespective of what was contained in the printed treaties that they were handling over political power to the Company making the various parties put diametrically opposing interpretations on the treaties they signed. Many of the coastal states, notably the Itsekiri Kingdom and Opobo, refused to accept the clauses which provided for free trade and for missionary activity. Missionaries were known to preach not only against polygamy but also against slave holding, an important institution in these states (Ade Ajayi, 1966, pp.80-81). It was also in consideration of British commercial interest that Brass signed Hewett's 'protection' treaty for a period of six months only. Moreover, many of the states had faced tasted the fiery justice which emanated from the gunboats and probably felt that provided they could guarantee their trade, it was just as well to sign the treaties rather than face bombardment.

It is significant that while a number of states raised objections to the clauses of the treaty which affected trade and labour, only Jaja of Opobo raised the political issue - the meaning of the word 'protection'. Consul Hewett hastened to assure Jaja that all that was meant was that Jaja was not to enter into treaties with other European powers without the permission of Britain (Anene, 1965, p.72). As for internal affairs, Jaja was assured that he was to continue to rule his people as before and that Britain had no intention of taking his land from him. It should be mentioned that this response from Consul Hewett which apparently gave Jaja the satisfaction he needed indicated that duplicity which was to mark Anglo-Nigerian relations throughout the period of colonial conquest. How could Jaja continue to rule his people as before when he was, by the treaty, denied jurisdiction over Europeans in his own territory? How could Jaja continue to rule his people as of old if, as laid down in Article $V$ of the treaty, he was bound to act on the advice of British consular officials in matters relating to the administration of justice, the development of the resources of the country, the interest of commerce, or in any other matter in relation to peace, order, and good government, and the general progress of civilisation? Whatever assurances Hewett may have given, there were provisions in the signed treaty which could provide adequate excuse for British intervention in the internal affairs of Jaja's Opobo and the other coastal states. Most probably as Ikime (1977:41) has noted, the rulers of these other coastal states did not, apparently, grasp this essential fact.

Although some historians and scholars have argued that it was not so much treaties and other agreements that determined the British success in the colonisation of Nigeria, as the naval superiority of Britain, it should be borne in mind that these treaties, together with those negotiated by the National African Company were important in the international 
bargaining for colonial territories that went on in Europe in the years after 1884. The Lower Niger and the delta were claimed by Britain as her spheres of influence on the basis of these treaties. Equally important, the same treaties provided Britain the bases, after the Berlin Conference, to proclaim a British Protectorate over what were described as the Oil Rivers. This led directly to the colonisation of Nigeria, and the evolution of the Nigerian states in the same. We pass over these problems which arose with the proclamation in 1885 of the British Protectorate of Oil Rivers as has well been documented by J. C. Anene (1965). Legally, the order-in-council which established the Protectorate did not give the consul any authority to intervene in the internal affairs of the Oil Rivers states, including control of trade.

However, it was the desire to control the trade of the coastal states that led the British naval commanders and consuls to get more and more involved in the internal politics of these states which led directly with the colonisation of Nigeria. This was driven first by the mercantile philosophy of 'God, Glory and Gold' and then by the colonial philosophy of 'Commerce, Christianity and Civilisation'. For Britain, there was a precise relation between Christianity and commerce and between evangelism and trade. There was however questions to be addressed as to which - Christianity, commerce or civilisation - either could, or should, be introduced first, in what forms and with what degree of overlap. In the British colonial diction, interference with trade had to mean the same as interference in local politics and this reality has been substantially documented by K. O. Dike (1956). A case in study which points to the undiluted involvement of Britain in both local trade and local politics was the deportation of King Jaja of Opobo which left the field free for British economic and political manoeuvres. Consistently, the British presented their interference as the need to actualise the White man's burden. Such burden presented them the obligation to rule over, and encourage the cultural development of people from other ethnic and cultural backgrounds until they can take their place in the world by fully adopting Western ways.

On Hewett's return to the delta after the deportation of Jaja, he sought to extend British authority from Okrika to the hinterland of Bonny. In July 1888 he signed a protection treaty with Okrika. In 1889, the British Foreign Office sent out a special commissioner in the person of Major (later Sir) Claude Macdonald to report on the future of the Oil Rivers (Ibid. p.87). The upshot of Macdonald's report, therefore, was the establishment of a more effective protectorate over the Oil Rivers with Macdonald as commissioner and consul-general. According to lkime (1977:54), the essential difference between the new administration set up in 1891 and the earlier consular authority was that whereas previously there was only one consul and assistant, now Macdonald established vice-consulates in all the delta states and had in addition customs and other staff. As from 1891 then, the British were clearly determined to formally bring the Oil Rivers and their hinterland under effective control.

The British, dominating commercial activities in the oil rivers, also had their fears. The British Consul in the oil rivers alerted his home government that the French might use their foothold in the Gabon to launch into the Cameroons and Igboland to control the sources of the palm oil trade (Akinrinade \& Folola, 2011, p.17). It was also at this time that reports began to file in from British traders on the Niger, led by George Tubman Goldie, of French competition and attempts to make treaties on the Niger. By the time Nana of Itsekiri fell, the British had already established viceconsulates at three points in the Western delta - Warri, Sapele, and Benin River. Warri and Sapele now became bases from which the penetration of the Urhobo, Isoko, and Ukwuani hinterland was organised. In September 1894 the Royal Niger Company signed treaties of protection with some 13 Urhobo towns including quite a number of those with whom the Niger Company had already entered into treaty relations (Ibid., p.21). Thus in 1899, the Royal Niger Company incurred responsibilities beyond its power to meet, and, in 1900, the political rights and duties entrusted to it by Charter were revoked. It lost its charter and became no more than a commercial enterprise with trading concern.

The British, in their dealings with the Yoruba, first established their influence in Lagos and Abeokuta. In 1861 Lagos became the first part of Nigeria to become a British colony. Once established in Lagos, it was only logical for the British to seek and extend their trade and influence into the Lagos hinterland. The military exploits of Ibadan and her efforts to replace the fallen Oyo as the centre of the Yoruba political system gave rise to the Ekiti Parapo - a combination of Ekiti and ljesha kingdoms, sworn to resist Ibadan's military aggression. Neither side was able to win a decisive victory and yet neither side would give in. In such circumstances both sides looked desperately for a third party that would intervene to bring the 16 year war to an end. The British willingly stepped in to negotiate peace between the warring parties and a peace treaty was negotiated and signed in 1886. The combatants agreed to put an end to war and to retire to their territories as agreed by the treaty. But they also agreed 'to submit themselves to such directions as may seem necessary or expedient to the Governor of Lagos for better more effectually securing the object of this Treaty' i.e. peace (Ikime, 1977, p.60). With peace now established in the hinterland, the British could at last extend their influence there and find a safe base to penetrate further. 


\section{Conclusion}

Any attempt to understand the ease and speed with which the British ran over the territory known today as Nigeria must begin with the use of treaties as legal and diplomatic instruments of commercial and political manipulation. Treaties played a major role in the furtherance of the motives of imperialism and the smooth overrun of the geographical space that came to be known as Nigeria in the name and spirit of colonialism. Colonialism did not account for as an example of the application of sovereignty; rather, sovereignty was constituted and shaped through colonialism. Although the declaration of Lagos as a British protectorate and later a colony was carried out in the spirit and fervour of imperialism, the accelerated interest of other colonial powers (especially France in West Africa), made it pertinent for the 'imperialism' to reach its highest stage - colonialism. Quite a number of treaties drawn up by Goldie were made with the chiefs of the lower Niger and the Hausa states. These treaties gave the use of force its moral backing because the British made it a rule rather than an exception of avenging the breach of any clause of the treaties with military force. Starting with the desire to use treaties in suppressing the overseas slave trade, the British made concerted effort at using treaties to survive the teething commercial competition with other European powers such as France and Germany.

\section{References}

Ade Ajayi, J. C. (1965). Christian Missions in Nigeria 1841-1871: The Making of an Educated Elite, London: Longman Group.

Akinrinade, S. \& Falola, T. (2011). Europe and Africa: Prelude to the Partition. In A. Sesay (Ed), Africa and Europe: From Partition to Independence or Dependence? New York: Routledge.

Anene, J. C. (1965). Southern Nigeria in Transition 1884-1906, Theory and Practice in a Colonial Protectorate. Cambridge: Longman Group.

Asiegbu, J. U. J. (1984). Nigeria and its British Invaders, 1851-1920: A Thematic Documentary History. New York: Nok Publishers.

Ayandele, E. A. (1966). The Missionary Impact on Modern Nigeria 1842-1914: A Political and Social Analysis. London: Longman Group.

Brett, E. A. (1973). Colonialism and Underdevelopment in East Africa: The Politics of Economic Change (1919-1939), New York: NOK Publishers Ltd.

Burns, J. \& Collins, R. (2007). History of Sub-Saharan Africa, Cambridge: Cambridge University Press.

Cain, J. G. \& Hopkins, A. G. (1980). The Political Economy of British Expansion Overseas, 1750-1914, The Economic History Review HER 33.

Crowder, M. (1966). West Africa Under Colonial Rule. London: Hutchinson \& Co.

Dike, K. O. (1956). Trade and Politics in the Niger Delta. Oxford: Clarendon Press.

Falola, T. \& Heaton, M. M. (2008). A History of Nigeria. New York: Cambridge University Press.

Hertslet, E. (1967). The Map of Africa by Treaty, Vol. I (British Colonies, Protectorates and Possessions in Africa). London: Frank Cass and Co. Ltd.

Hobsbawm, E. (1987). The Age of Empire: 1875-1914, London: Oxford University Press.

Hopkins, A. G. (1975). An Economic History of West Africa. London: Longman Publishers

Ikime, O. (1977). The Fall of Nigeria: The British Conquest. London \& Ibadan: Heinemann Education Books.

Orugbani, A. (2005). Nigeria Since the $19^{\text {th }}$ Century. Port Harcourt: Paragraphic Press.

Ryder, A. F. C. (1969). Benin and the Europeans, 1485-1897. London: Longman.

Tamuno, T. N. (1965). Some Aspects of Nigerian Reaction to the Imposition of British Rule, Journal of the Historical Society of Nigeria, 3 (2).

Uzoigwe, G. N. (1985). European Partition and Conquest of Africa: An Overview. In A. Adu Boahen, (Ed.) General History of Africa VII, Berkeley: MIT Press. 